\title{
Pendekatan Open-Ended dalam Mempengaruhi Kemampuan Mengenal Konsep Bilangan Anak Usia Dini
}

\author{
Rohmalina Rohmalina ${ }^{\bowtie}$, Ema Aprianti², Ririn Hunafa Lestari ${ }^{3}$ \\ Pendidikan Guru Pendidikan Anak Usia Dini, Institut Keguruan dan Ilmu Pendidikan \\ Siliwangi
}

DOI: $10.31004 /$ obsesi.v5i2.805

\begin{abstract}
Abstrak
Kemampuan lambang bilangan bagi anak usia dini penting dirangsang untuk memahami konsep matematika dijenjang pendidik selanjutnya. Akan tetapi pemahaman guru dalam mengajarkan matematika yang baik dan tepat masih kurang, sehingga dilakukan penelitian terkait dengan konsep bilangan terhadap pendekatan open-ended sebagai metode pembelajaran anak usia dini. Metode yang digunakan dalam penelitian ini adalah kuasi eksperimen dengan sampel penelitian adalah anak-anak dari kelas A yang terbagi menjadi dua kelas dengan menggunakan lembar observasi sebagai teknik pengumpulan data yang kemudian dianalisis dengan menggunakan uji t. Hasil penelitian menunjukkan data pre-test pada dua kelas memiliki kemampuan yang sama. Setelah diberikan treatment dan dilakukan post-test diperoleh perhitungan uji statistik menggunakan $\mathrm{t}$-test bahwa terdapat perbedaan konsep bilangan anak usia dini setelah diberikan pembelajaran dengan pendekatan openended, sehingga anak usia dini mampu menyelesaikan konsep bilangan matematika yang bersifat abstrak melalui pembelajaran yang terbuka dengan memberikan kesempatan kepada anak dalam memecahkan masalah sendiri.
\end{abstract}

Kata kunci: pendekatan open-ended; konsep bilangan; anak usia dini.

\begin{abstract}
The ability of number symbols for early childhood is important to be stimulated to understand mathematical concepts at the next level of educators. However, the teacher's understanding of teaching good and precise mathematics is still lacking, so that research is carried out related to the concept of numbers to the open-ended approach as a method of learning early childhood. The method used in this research is quasi-experimental research. The research sample is children from class A who are divided into two classes using the observation sheet as a data collection technique which is then analyzed using the t-test. The results showed that the pre-test data in the two classes had the same ability. After being given treatment and carrying out a post-test, it was obtained statistical test calculations using the t-test that there were differences in the concept of early childhood numbers after being given learning with an open-ended approach, so that early childhood was able to complete abstract mathematical number concepts through open learning by providing opportunities for children to solve their problems.
\end{abstract}

Keywords: open-ended approach; the concept of numbers; early childhood.

Copyright (c) 2020 Rohmalina Rohmalina, Ema Aprianti, Ririn Hunafa Lestari

$\triangle$ Corresponding author:

Email Address: rohmalina@ikipsiliwagi.ac.id (Bandung, Jawa Barat)

Received 2 October 2020, Accepted 7 November 2020, Published 23 November 2020 


\section{PENDAHULUAN}

Dalam pendidikan anak usia dini salah satu kawasan yang harus dikembangkan adalah bidang pengembangan kognitif berdasarkan KEMENDIKBUD (2014). Salah satu aspek yang perlu dikembangkan pada pendidikan pra sekolah adalah perkembangan kognitif. Perkembangan kognitif dapat diartikan dengan kemampuan belajar dalam berfikir atau kecerdasan yaitu kemampuan untuk mempelajari keterampilan dan konsep baru, keterampilan untuk memahami apa yang terjadi di lingkungannya, serta keterampilan menggunakan daya ingat dan menyelesaikan soal-soal sederhana (Bacaan \& Tua, 2011). Diharapkan, stimulus kemampuan kognitif yang baik dan tepat melalui berbagai macam program pengembangannya akan menghasilkan salah satu kemampuan yang dibutuhkan yaitu kemampuan berpikir kritis (Aubrey et al., 2012)

Tahap perkembangan kognitif pada anak ditandai dengan dua tahap yaitu berpikir dengan objek yang realistis dan berfikir simbolis atau sistematis, dimana berpikir anak menggunakan simbol-simbol, seperti huruf dan angka (Nasional, 2007). Perkembangan kognitif pada anak dapat dirangsang sejak dini dengan memperkenalkan lambang-lambang huruf dan bilangan, sehingga anak dapat mengolah dan menggunakan makna lambang tersebut dalam kehidupan sehari-hari berdasarkan Keller, Hart, \& Martin (2001) yang menyatakan bahwa konsep lambang bilangan merupakan dasar dari pembelajaran matematika yang dapat diperkenalkan kepada anak sejak dini. Salah satu lambang yang akan dikenalkan pada anak sejak dini yaitu lambang bilangan, sebab dalam kehidupan sehari-hari anak tidak terlepas dari konsep matematika yang terorganisasi secara sistematik dengan membahas penalaran yang logik dan masalah yang melibatkan bilangan, ruang dan waktu sehingga dibutuhkan berbagai ide untuk memahami dan menguasai permasalahan social, ekonomi dan alam (Suwardi, Firmiana, \& Rohayati, 2016; Ma'Rifah \& Widada, 2019).

Apabila anak memahami atau mengenal salah satu pemahaman tentang lambang bilangan, anak akan mudah beradaptasi dan menyelesaikan permasalahan yang ada disekitar lingkungannya. Lambang bilangan perlu diperkenalkan kepada anak sedini mungkin karena bilangan merupakan dasar bagi pengembangan kemampuan matematika. Kemampuan mengenal lambang bilangan bagi individu merupakan suatu hal yang penting bagi proses bertahan hidup, karena sejak dini anak sudah mulai mengenal dan menggali berbagai dimensi matematis dari dunia mereka (Inawati, 2011, hlm. 6).

Maka dari itu lambang bilangan yang merupakan bagian dari pembelajaran matematika memiliki peranan penting sehingga matematika perlu dikenalkan dan diajarkan sejak dini sebagai persiapan anak dalam melanjutkan pendidikan selanjutnya (Wulandari, Dantes, \& Antara, 2020; Danic, Japa, \& Diputra, 2019). Berdasarkan hasil Trend in International Mathematics and Science Study (TIMSS) sebagai studi internasional tentang mengukur kecenderungan perkembangan matematika dan sains menyatakan bahwa tahun 2015 Indonesia berada diperingkat 45 dari 50 negara (Wulandari et al., 2020)

Akan tetapi, pendidik yang mengajarkan matematika sejak dini yang tidak menguasai pemahaman terhadap konsep matematika, metode pengajaran, media pembelajaran dan proses pelaksanaan akan mempengaruhi pengalaman belajar anak, sehingga cara berpikir kritis, munculnya karakter anak seperti sikap ilmiah, disiplin, bertanggung jawab tidak akan terstimulus dengan baik dan tepat (Suwardi et al., 2016), sehingga dibutuhkan pendidik yang memiliki kompetensi pedagogic yang kuat dapat memahami kebutuhan anak dalam memperoleh suatu konsep khususnya dalam mengajarkan matematika kepada anak sejak dini agar anak siap dalam beradaptasi dengan masa transisi di sekolah dasar (Winitri \& Nurani, 2020; Munroe, 2015), hal ini sesuai dengan penelitian yang dilakukan oleh Björklund (2015) bahwa kompetensi pedagogis pendidik memiliki peran penting dalam mengajarkan matematika kepada anak. Selain itu pada pelaksanaan pembelajaran ditemukan data bahwa masih terbatas dan kurang bervariasinya penggunaan media pembelajaran ketika kegiatan belajar mengajar berlangsung, sebagian besar kegiatan mengenal lambang bilangan masih menggunakan LKA (Lembar Kerja Anak), buku tulis dan pensil. 
Tidak hanya itu Farikhah \& Ariestina (2020) memperoleh hasil data bahwa salah satu permasalahan yang muncul dikarenakan tuntutan masyarakat salah satunya adalah orang tua dari peserta didik yang bersekolah di Taman kanak-kanak (TK) dengan tujuan setelah peserta didik lulus, peserta didik dapat membaca, menulis dan berhitung. Meskipun pemaknaan berhitung pada pendidikan khususnya pada anak usia dini bukan menekankan bagaimana cara anak mampu dalam operasi hitungan bilangan melainkan anak-anak dapat memahami kehidupan melalui matematika, sehingga peran guru perlu diperhatikan dalam proses pelaksanaan pembelajaran matematika dengan tujuan bahwa anak akan memiliki ketertarikan secara alami terhadap matematika tanpa adanya paksaan, sebab pada jenjang pendidikan selanjutnya pelajaran matematika menjadi salah satu pelajaran dengan nilai prestasi yang rendah (Nurkamilah et al., 2018).

Berdasarkan surat edaran Menteri Pendidikan Nasional No. 1839/C.C2/Tu/2009 menegaskan bahwa TK tidak diperbolehkan memberikan pembelajaran calistung secara langsung kepada peserta didik melainkan pembelajaran tersebut perlu direncanakan dalam kerangka pengembangan seluruh aspek tumbuh dan kembang anak melalui pendekatan bermain yang disesuaikan dengan aspek perkembangan anak berdasarkan usia anak (dalam Farikhah \& Ariestina, 2020)

Permasalahan tersebut dapat dijadikan acuan pendidik dalam berinovasi menggunakan berbagai macam pendekatan, strategi, metode dan media pembelajaran agar ketertarikan anak terhadap pembelajaran matematika muncul dari dalam diri anak. Maka dari itu, peneliti mencoba pendekatan open-ended terhadap pembelajaran matematika di pendidikan anak usia dini sebab diperoleh hasil bahwa nilai signifikansi yang diperoleh yaitu 0.000 sehingga nilai sig $<0.05$ artinya $\mathrm{H}_{0}$ ditolak sehingga kemampuan berpikir kritis matematis dan kepercayaan diri siswa menengah pertama melalui pendekatan open-ended di kota Cimahi meningkat (Novtiar \& Aripin, 2017). Dari hasil penelitian tersebut, peneliti mencoba pendekatan pembelajaran open-ended di PAUD khususnya pada kemampuan mengenal lambang bilangan sebagai bagian dari pelajaran matematika untuk anak usia dini sesuai dengan standar National Council of Teacher of Mathematics.

Pengajaran matematika yang diberikan kepada anak sejak dini memiliki prinsip dan standar yang direkomendasikan oleh National Council of Teacher of Mathematics (NCTM) (dalam Martin, 1998) terdiri dari standar isi dan standar proses. Standar isi pembelajaran matematika meliputi bilangan dari operasi bilangan, aljabar, bentuk geometri, pengukuran serta analisis data dan probalbilitas, sedangkan standar proses meliputi pemecahan masalah, penalaran dan pembuktian, komunikasi, koneksi dan representasi (Sriningsih, 2009; Martin, 1998). Pada penelitian ini kemampuan mengenal konsep bilangan menjadi perhatian peneliti dalam mengajarkan matematika kepada anak sejak dini dalam tingkat pencapaian perkembangan kognitif anak sesuai dengan Peraturan Mentri Pendidikan dan Kebudayaan (KEMENDIKBUD) tahun 2014 tentang Standar Tingkat Pencapaian Perkembangan Anak.

Proses pembelajaran dengan menggunakan open-ended merupakan proses pembelajaran yang memberikan permasalahan terhadap konsep matematika yang akan dibahas oleh pendidik kepada peserta didik dengan sifat terbuka dengan maksud pendidik memberikan tantangan kepada peserta didik dalam menjawab tantangan tersebut dengan berbagai macam solusi pemecahannya. Tidak hanya memberikan berbagai macam solusi dalam memecahkan masalah, makna sifat terbuka adalah memberikan kesempatan kepada peserta didik dalam memecahkan masalahnya dengan caranya sendiri namun tetap benar (Faridah et al., 2016).

Berdasarkan beberapa kajian literatur, diperoleh hasil bahwa pendekatan pembelajaran dengan menggunakan open-ended mampu merangsang kemampuan matematika peserta didik, sehingga peneliti mencoba menerapkan pendekatan open-ended dalam merangsang kemampuan matematika untuk anak usia dini sebab salah satu kemampuan yang dirangsang adalah kemampuan memecahkan masalah. Melalui kemampuan memecahkan masalah yang dirangsang dengan baik dan tepat diberikan kepada 
anak usia dini dapat memberikan pengalaman dalam membuktikan kemungkinan dari permasalahan tersebut, yang dilanjutkan dengan diskusi dan menarik kesimpulan (Lopes et al., 2017). Oleh karena itu, penelitian ini bertujuan untuk mengetahui pengaruh pendekatan pembelajaran open-ended terhadap kemampuan mengenal lambang bilangan sebagai bagian pelajaran matematika yang perlu diperkenalkan anak sejak dini.

\section{METODOLOGI}

Metode penelitian yang digunakan adalah metode kuasi eksperimen dengan pendekatan kuantitatif dimana penelitian memiliki dua kelas yang akan dilakukan penelitiannya yaitu kelas eksperimen dan kelas control dengan tujuan mengetahui pengaruh kelas eksperimen yang diberikan treatment yaitu pembelajaran dengan pendekatan openended dan kelas control yang menggunakan pembelajaran konvensional terhadap kemampuan mengenal lambang bilangan melalui one-grup pre-test-pos-test desain dimana peneliti melakukan pretest sebelum diberi pendekatan open-ended dan posttest setelah diberikan pendekatan open-ended dengan tujuan membandingkan hasil penelitian sebelum dan sesudah diberikan pendekatan open-ended. Penentuan sampel penelitian, peneliti menggunakan desain the non equivalent control group design sebagai desain metode penelitian yang digunakan dengan tujuan penelitian ini sampel penelitian kelompok eksperimen dan kelompok control tidak dipilih secara acak sehingga peneliti menerima keadaan sampelnya, sample yang digunakan adalah salah satu Taman Kanak-kanak (TK) yang berada di kecamatan Cimahi Tengah (Ruseffendi, 2010; Sugiyono, 2017). Teknik pengumpulan data yang digunakan dalam penelitian ini adalah observasi dengan cara mengamati proses pelaksanaan pembelajaran anak usia dini pada tahap pretest, pemberian pembelajaran openended sebagai treatment yang diberikan dan tahap posttest (Arikunto, 2010). Setelah data terkumpul, peneliti akan menganalisis data dengan menggunakan uji t-test jika data tersebut memenuhi syarat uji t-test yaitu data dari pre-test dan post-test telah dinyatakan berdistribusi normal (Sugiyono, 2017). Adapun bagan 1 menjelaskan bagaimana alur dari tahapan-tahapan penelitian yang digunakan sebagai berikut:

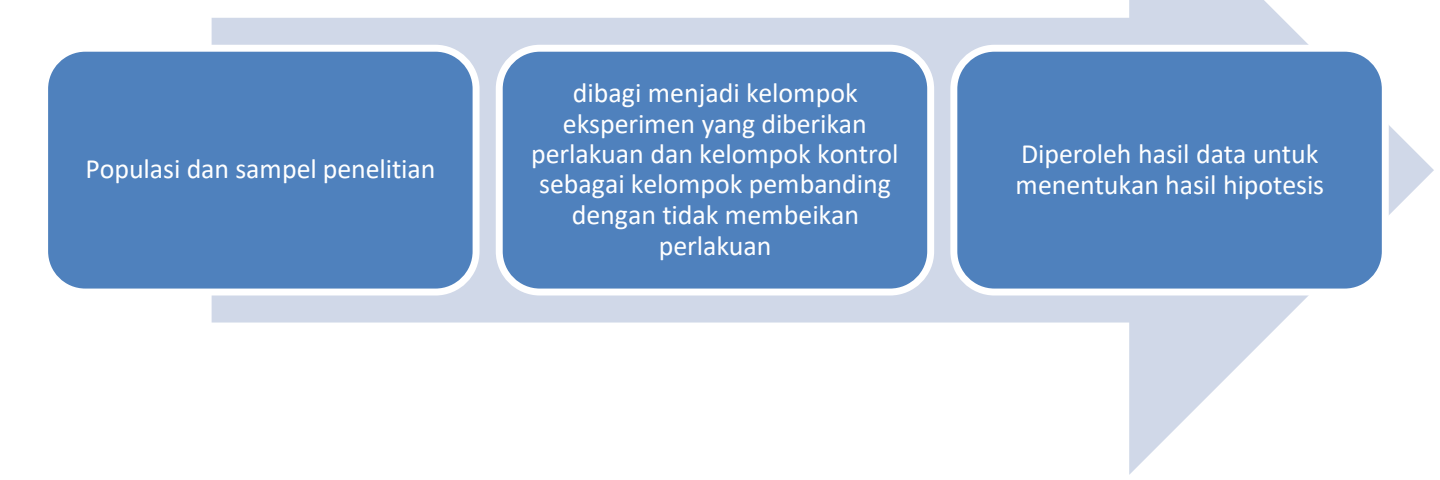

Bagan 1. Tahapan-tahapan proses pelaksanaan penelitian dengan metode penelitian kuasi eksperimen

\section{HASIL DAN PEMBAHASAN}

\section{Keadaan Awal Kemampuan Mengenal Lambang Bilangan Kelompok A}

Tahap awal dalam penelitian ini yaitu melakukan pretest pada kelompok eksperimen dan kelompok kontrol. Pretest dilakukan dengan maksud untuk mengetahui kemampuan awal anak yang akan dijadikan sebagai subjek penelitian, yakni untuk mengetahui kemampuan awal mengenal lambang bilangan. Pada penelitian ini kemampuan mengenal lambang bilangan yakni mencakup mengenal, membilang, dan menunjukkan konsep bilangan dalam bentuk delapan item pernyataan dalam bentuk instrument penelitian. 
Pendekatan Open-Ended dalam Mempengaruhi Kemampuan Mengenal Konsep Bilangan Anak Usia Dini DOI: $10.31004 /$ obsesi.v5i2.805

Tabel 1. Hasil Uji Normalitas Data Pre-test pada Kelompok Eksperimen dan Kelompok Kontrol

Tests of Normality

\begin{tabular}{|ll|r|r|r|r|r|r|}
\hline \multirow{2}{*}{} & \multirow{2}{*}{ kelompok } & \multicolumn{3}{|c|}{ Kolmogorov-Smirnov $^{\text {a }}$} & \multicolumn{3}{|c|}{ Shapiro-Wilk } \\
\cline { 3 - 8 } & Statistic & \multicolumn{1}{c|}{ df } & \multicolumn{1}{c|}{ Sig. } & \multicolumn{1}{c|}{ Statistic } & \multicolumn{1}{c|}{ df } & \multicolumn{1}{c|}{ Sig. } \\
\hline \multirow{2}{*}{ skor_pretest } & eksperimen & .181 & 10 & .200 & .852 & 10 & .061 \\
& kontrol & .249 & 8 & .155 & .875 & 8 & .168 \\
\hline
\end{tabular}

*. This is a lower bound of the true significance.

a. Lilliefors Significance Correction

Pada tabel komogrorov-smirnov yang ditampilkan pada tabel satu menunjukkan nilai signifikansi 0.200 untuk kelompok eksperimen dan 0.155 untuk kelompok control sehingga dapat disimpulkan bahwa kriteria pengujian dalam uji normalitas, jika di peroleh hasil nilai sig < 0,05 maka distribusi datanya adalah tidak normal, sedangkan jika diperoleh hasil > 0,05 maka distribusi datanya adalah normal. Berdasarkan data hasil pengujian normalitas di atas, diketahui jika hasil data kelompok eksperimen dan kelompok control memiliki nilai sig lebih besar dari 0.05, maka dari itu dapat disimpulkan bahwa data pretest kelompok eksperimen dan kelompok kontrol berdistribusi normal.

Tabel 2. Hasil Uji t Independent Data Pre-test Kelompok Eksperimen Dan Kelompok Kontrol

Independent Samples Test

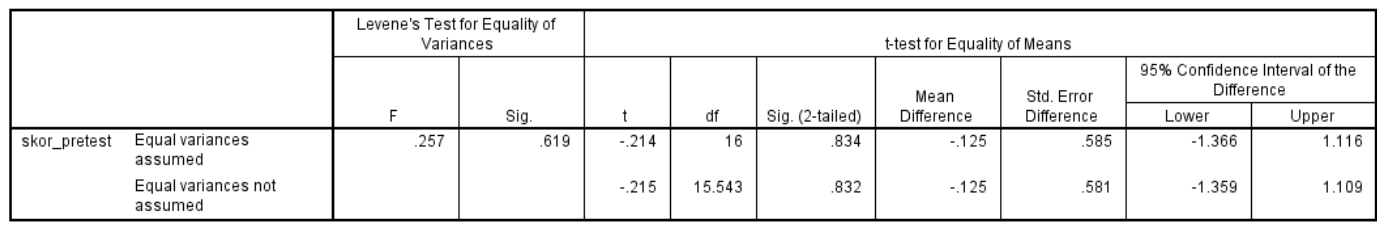

Setelah diperoleh hasil data pretest berdistribusi normal maka data diolah kembali dengan menggunkan uji $t$ dan diperoleh hasil pretest kelompok eksperimen dan kelompok kontrol. Berdasarkan hasil tabel dua diperoleh nilai signifikansi uji $t$ independent 0. 834, sehingga diperoleh kesimpulan hipotesis nilai signikansi 0,834>0.05 dengan kata lain hasil pretest kelompok eksperimen dan kelompok kontrol menunjukkan tidak terdapat perbedaan yang signifikan sehingga pada saat pretest tingkat kemampuan mengenal lambang bilangan pada kelompok eksperimen dan kelompok kontrol tidak memiliki perbedaan. Adapun perhitungan mean dari kedua kelompok untuk menjelaskan kategori kemampuan mengenal konsep lambang bilangan yaitu kelompok eksperimen yang berada dalam kategori sedang yakni $70 \%$ dan $30 \%$ dalam kategori rendah, sedangkan pada kelompok kontrol terdapat 75 $\%$ anak dalam kategori sedang dan $25 \%$ dalam kategori rendah. Berdasarkan persentasi tersebut menunjukkan bahwa anak yang berada dalam kelompok eksperimen maupun kelompok kontrol mayoritas berada dalam kategori sedang, dengan demikian dapat ditarik kesimpulannya bahwa berdasarkan hasil pretest menunjukkan tidak ada perbedaan kemampuan mengenal lambang bilangan pada kelompok eskperimen dan kelompok kontrol, yakni kemampuan awal mengenal lambang bilangan pada kelompok eksperimen dan kelompok kontrol masih berada dalam kategori sedang dan kategori rendah.

\section{Keadaan Akhir Kemampuan Mengenal Lambang Bilangan Kelompok A}

Sebelum diberikannya post-test pada kelompok eksperimen dan kelompok kontrol, terlebih dahulu diberikan treatment dalam bentuk pendekatan pembelajaran open-ended pada kelompok eksperimen dan kelas kontrol menggunakan pembelajaran konvensional seperti biasa yang dilakukan dalam kelas kontrol. Berdasarkan hasil persentase data post-test diperoleh hasil terdapat perbedaan yang signifikan dalam kemampuan mengenal lambang 
bilangan pada kelompok eksperimen dengan menggunakan pendekatan pembelajaran openended pada kelompok eksperimen dibandingkan dengan hasil posttest kelompok kontrol.

Keadaan akhir pada kelompok eksperimen menunjukkan kemampuan mengenal lambang bilangan mengalami perbedaan yang signifikan setelah diterapkannya pendekatan pembelajaran open-ended dibandingkan dengan kelompok kontrol yang menggunakan pembelajaran konvensional. Hal ini dapat dibuktikan dari hasil perhitungan data post-test yang sebelumnya sudah diberikan treatment yang berbeda pada kelompok eksperimen dan kelompok kontrol. Berdasarkan data post-test dari kelompok eksperimen, hasil penelitian ini menunjukkan adanya pengaruh signifikan pada kelompok eksperimen. Hal tersebut dibuktikan berdasarkan hasil uji t-independent dari data post-test kelompok eksperimen dan kelompok kontrol yakni nilai signifikansi menunjukan 0,000 berarti bahwa nilai sig. $0.000<$ 0.05, sehingga Ho ditolak dan Ha diterima, yang berarti terdapat perbedaan yang signifikan pada pembelajaran pendekatan open-ended terhadap kemampuan mengenal lambang bilangan.

Dalam skenario pembelajaran matematika khususnya kepada anak usia dini, pendidik memiliki peran penting. Pendidik yang baik merupakan pendidik yang dapat menguasai materi pembelajaran dan ilmu mengajar (Leon dalam Novianty, 2018). Pada pembelajaran matematika, peran pendidik sebagai fasilitator dan motivator dalam scenario pembelajaran dituntut memiliki kemampuan yang cakap dalam mengajarkan matematika yang berkesan dan menyenangkan sesuai dengan pendekatan pembelajaran anak usia dini seperti metode, media yang cocok untuk melakukan kegiatan pengembangan matematika anak di sekolah (Novianty, 2018; Wahyudin \& Agustin, 2011; Muin, 2016; Ma'Rifah \& Widada, 2019). Maka dari itu peneliti telah melakukan analisis terhadap beberapa kajian literatur yang berkaitan dengan pendekatan pembelajaran open-ended, konsep bilangan dan pendidikan anak usia dini.

Berdasarkan hasil penelitian yang telah dijelaskan pada point hasil, diperoleh hasil bahwa setelah diberikan stimulus diperoleh hasil terdapat perbedaan yang signifikan terhadap kemampuan konsep bilangan yang terdiri dari membilang banyak benda, mengurutkan bilangan, mengenal konsep bilangan dan mengenal lambang bilangan (Ministry of Education and Culture of Republic Indonesia, 2014) setelah diterapkan pendekatan pembelajaran open-ended.

Pengenalan konsep bilangan di prasekolah merupakan langkah awal dalam menumbuh kembangkan kemampuan berhitung yang terampil dalam menghadapi suatu permasalahan pada kehidupan sehari-hari sebagai acuan pendidik dalam mengajarkan pembelajaran matematika dalam bentuk aktivitas permainan sesuai dengan prinsip pembelajaran anak usia dini (Sumardi, Rahman, \& Gustini, 2017; Wahyudin \& Agustin, 2011; Rahman et al., 2017). Selain itu pengenalan konsep bilangan perlu diperkenalkan dengan tujuan mempersiapkan anak dalam mengikuti pendidikan selanjutnya hingga memasuki dunia kerja (Sumardi, Rahman, \& Gustini, 2017; Muin, 2016; Roliana, 2018).

Konsep bilangan yang diperkenalkan dan diajarkan oleh pendidik merupakan dasar dari aritmatika dalam memecahkan permasalahan, sebab pembelajaran matematika identik menggunakan simbol-simbol angka dalam penyampaian suatu konsep pengetahuan. Dalam pembelajaran dengan tujuan memperkenalkan bilangan kepada anak, anak akan mengingat nama bilangan sebagai awal memperkenalkan suatu konsep bilangan tetapi anak belum mengerti makna dari bilangan yang anak sebutkan akan tetapi seiring waktu dan bertambahnya pengalaman belajar, anak akan mengerti dari makan bilangan bahkan anak akan dapat memaknai dan membaca simbol-simbol bilangan (Rahman et al., 2017; Sumardi et al., 2017; Nopayana, Rostika, \& Ismail, 2018).

Maka dari itu peneliti mencoba menggunakan pendekatan open-ended sebagai salah satu pendekatan pembelajaran dalam memperkenalkan konsep bilangan kepada anak sebab pendekatan pembelajaran open-ended memiliki kesamaan dalam metode pembelajaran anak usia dini yaitu problem solving dimana anak diberikan suatu masalah yang harus 
diselesaikan. Pendekatan pembelajaran open-ended merupakan pembelajaran yang memposisikan peserta didik dalam proses memecahkan masalah dengan berbagai macam jawaban berdasarkan kemampuan peserta didik dalam mengetahui informasi agar alasan yang diberikan peserta didik dalam menjawab sesuai dengan pengetahuannya (Novtiar \& Aripin, 2017; Chanifah, 2014; Faridah et al., 2016).

Pada saat diberikan stimulus melalui pendekatan pembelajaran open-ended kepada anak, guru mempersiapkan pembelajaran dengan memberikan permasalahan yang sama kepada setiap anak setelah itu guru mencoba memberikan kesempatan kepada anak untuk menyelesaikan permasalahan tersebut contoh cara penyelesaiannya akan tetapi guru membebaskan anak untuk menyelesaikan permasalahan tersebut dengan bantuan media yang sudah dibuat guru yaitu media piring kertas angka yang bertujuan untuk mempermudah anak memahami lambang bilangan. Pada penelitian ini peneliti menggunakan pendekatan pembelajaran open-ended terhadap konsep bilangan melalui media dan sumber belajar dengan memanfaatkan lingkungan yaitu dengan berinovasi dengan piring kertas yang dituliskan bilangan angka agar menarik minat belajar secara visual seperti pada gambar 1 . Dalam memahami lambang bilangan melalui media piring kertas tersebut guru hanya memberikan pemahaman tentang konsep bilangan melalui ucapan yang kemudian anak mencari lambang bilangan tersebut sesuai dengan pemahaman dan kemampuan yang anak miliki.

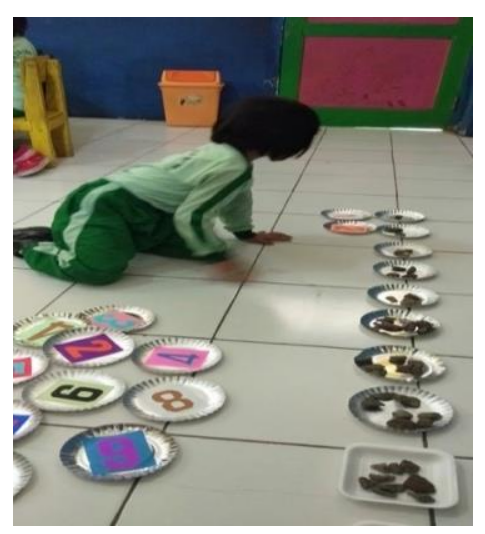

\section{Gambar 1 Inovasi pada media pembelajaran}

Berdasarkan hasil penelitian tersebut, tahapan yang telah guru terapkan disesuaikan dengan tahapan pembelajaran dengan pendekatan open-ended pada umumnya yang diajarkan pada usia tinggi meliputi 1) menghadapkan peserta didik pada masalah terbuka dengan maksud permasalahan tersebut dapat diselesaikan dengan berbagai macam cara sesuai kemampuan peserta didik, 2) pendidik memberikan kesempatan kepada peserta didik dalam mencari, menemukan dan membangun pengetahuannya sendiri dalam menyelesaikan permasalahan yang dihadapinya, 3) Setelah itu, peserta didik diberikan kesempatan dalam mencari solusi untuk menyelesaikan permasalahan tersebut sesuai dengan pengetahuannya yang telah dibangun sebelumnya, 4) peserta didik diminta untuk menyajikan hasil temuannya selama proses penyelesaian masalah (Novtiar \& Aripin, 2017; Chanifah, 2014; Faridah et al., 2016).

Akan tetapi tahapan pembelajaran dengan pendekatan open-ended yang telah dijelaskan sebelumnya telah diadaptasi oleh pendidik PAUD dalam mengajarkan dan memperkenalkan konsep bilangan kepada anak usia dini dengan memperhatikan pendekatan pembelajaran anak usia dini yang meliputi dari 1) kebutuhan anak, 2) belajar melalui bermain atau bermain seraya belajar, 3) pendekatan kreatif dan inovatif, 4) lingkungan yang kondusif, 5) menggunakan pembelajaran terpadu, 6) mengembangkan kecakapan hidup, menggunakan berbagai media dan sumber belajar, 7) pembelajaran yang berorientasi pada prinsip-prinsip 
perkembangan anak, 8) stimulasi terpadu (Wahyudin \& Agustin, 2011). Pada saat pemberian treatment, terlihat anak-anak sangat menyukainya dikarenakan anak-anak mencari penyelesaian masalah tersebut dengan kemampuan dan pemahaman yang dimiliki anak sebelumnya sehingga anak tertantang dalam menyusun strategi dalam menyelesaikannya. Hal ini sesuai dengan hasil penelitian yang dilakukan oleh Freiman (2018) bahwa melalui pembelajaran dengan pendekatan open-ended anak berada pada situasi yang menantang dalam menyelesaikan permasalahan matematika. Pada penelitian ini peneliti menggunakan pendekatan pembelajaran open-ended terhadap konsep bilangan melalui media dan sumber belajar dengan memanfaatkan lingkungan yaitu dengan berinovasi dengan piring kertas yang dituliskan bilangan angka agar menarik minat belajar secara visual seperti pada gambar 2 .

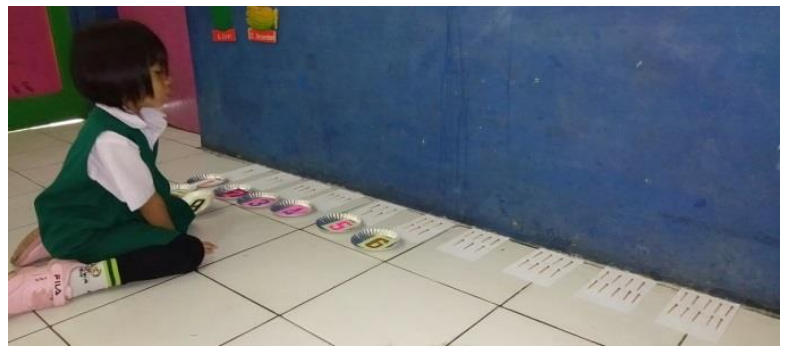

\section{Gambar 2. Proses Pembelajaran melalui Media Piring Kertas}

Setelah diberikan pendekatan pembelajaran open-ended sebagai treatment yang akan diberikan kepada kelas eksperimen, diperoleh hasil bahwa terdapat perbedaan yang signifikan dibandingkan kelas kontrol yaitu nilai signifikansi 0,000 untuk kelas eksperimen. Melalui pendekatan pembelajaran open-ended terhadap konsep bilangan kepada anak usia dini, memberikan kesempatan kepada anak dalam memecahkan masalah yang diberikan guru dan memperkenalkan konsep bilangan sebagai kebutuhan anak yang mendasar dalam memperkenalkan konsep matematika dengan menggunakan media dan sumber belajar yang mudah diperoleh dan dibuat dengan kreatif oleh pendidik (Sriningsih, 2009;Wahyudin \& Agustin, 2011).

Tidak hanya diperoleh hasil perbedaan setelah diberikan treatment, peneliti menemukan hasil bahwa melalui pendekatan pembelajaran open-ended terhadap konsep bilangan, anak cenderung bertindak secara positif terhadap matematika baik dalam bentuk sikap yang ditampilkan anak dalam mengolah pengetahuan matematika yang telah dibangunnya dari pengalaman yang menyenangkan, menarik serta kesempatan yang diberikan pendidik dalam menggambarkan dunianya secara matematis (Nurkamilah et al., 2018). Melalui pendekatan pembelajaran open-ended memunculkan kreativitas sebagai sikap yang dihasilkan dari pembelajaran ini dalam mengatasi pemecahan masalah yang berkaitan dengan matematika baik dalam standar isi maupun standar proses (Faridah et al., 2016; Martin, 1998)

\section{SIMPULAN}

Berdasarkan hasil penelitian yang telah diperoleh bahwa terdapat perbedaan konsep bilangan anak usia dini terhadap pendekatan pembelajaran dengan menggunakan pendekatan open-ended pada kelompok eksperimen. Hal ini dapat terlihat dari proses pengolahan data bahwa setelah diberikan treatment diperoleh perhitungan uji statistik menggunakan t-test bahwa nilai $p$ value yaitu $0.000<0.05$. Adapun hal yang perlu diperhatikan ketika matematika diperkenalkan kepada anak usia dini yaitu memperhatikan kebutuhan, karakteristik, tahapan usia anak serta pendekatan pembelajaran anak seperti metode pengajaran, media serta konsep matematika agar anak memiliki pengalaman pembelajaran yang menyenangkan ketika belajar matematika agar dijenjang pendidikan selanjutnya anak siap menerimanya. 


\section{UCAPAN TERIMA KASIH}

Peneliti mengucapkan terima kasih sedalam-dalamnya kepada berbagai pihak yaitu pihak lembaga Intitut Keguruan dan Ilmu Pendidikan (IKIP) Siliwangi serta staf dan rekan di Prodi Pendidikan Guru-Pendidikan Anak Usia Dini (PG-PAUD) yang telah berperan, membantu dan mendukung peneliti sehingga peneliti dapat melaksanakan penelitian dan menyelesaikan karya ilmiah ini. Tidak hanya itu, peneliti pun berterimakasih kepada pihak sekolah khususnya guru dan anak-anak di salah satu Taman Kanak-kanak (TK) di salah satu kota Cimahi atas kerjasamanya selama peneliti melakukan penelitian.

\section{DAFTAR PUSTAKA}

Arikunto. (2010). Prosedur penelitian atau pendekatan praktik. Rineka Cipta.

Aubrey, C., Ghent, K., \& Kanira, E. (2012). Enhancing thinking skills in early childhood. International Journal of Early Years Education, 20(4), 332-348. https://doi.org/10.1080/09669760.2012.743102

Bacaan, S., \& Tua, O. (2011). Mengasah Kecerdasan di Usia 4-6 tahun.

Björklund, C. (2015). Pre-primary school teachers' approaches to mathematics education in Finland. Varhaiskasvatuksen Tiedelehti Journal of Early Childhood Education Research, 4(2), 69-92.

Chanifah, N. (2014). Peningkatan Kreativitas Siswa Menggunakan Model Pembelajaran OpenEnded Smp Sultan Agung Purworejo. Ekuivalen-Pendidikan Matematika, 12(3), 191-196.

Danic, I., Japa, I. G. N., \& Diputra, K. S. (2019). Penguatan Kemampuan Pemecahan Masalah Matematika Siswa Melalui Pembelajaran Matematika Realistik Berbasis Open-Ended. Jurnal Ilmiah Pendidikan Citra Bakti, 6, 9-22. https://doi.org/10.1017/CBO9781107415324.004

Faridah, N., Novianti, E., \& Kurniadi, Y. (2016). Pendekatan Eksploratif Untuk Meningkatkan Kemampuan. Jurnal Pena Ilmiah, 1(1).

Farikhah, S., \& Ariestina, H. (2020). Menelisik Kurikulum Paud: Kajian Fenomenologis Terhadap Kecenderungan Belajar Calistung Anak Usia Dini. Preschool (Jurnal Perkembangan Dan Pendidikan Anak Usia Dini), 1(2), 77-94. https://doi.org/https:// doi.org/10.18860/preschool.v1i2.9058

Freiman, V. (2018). Complex and Open-Ended Tasks to Enrich Mathematical Experiences of Kindergarten Students (pp. 373-404). https:// doi.org/10.1007/978-3-319-73156-8_14

Keller, B. A., Hart, E. W., \& Martin, W. G. (2001). Illuminating NCTM's Principles and Standards for School Mathematics. School Science and Mathematics, 101(6), 292-304. https://doi.org/10.1111/j.1949-8594.2001.tb17960.x

Lopes, C. E., Grando, R. C., \& D'Ambrosio, B. S. (2017). Experiences Situating Mathematical Problem Solving at the Core of Early Childhood Classrooms. Early Childhood Education Journal, 45(2), 251-259. https:/ / doi.org/10.1007/s10643-016-0775-0

Ma'Rifah, N., \& Widada, W. (2019). Pembelajaran TAI dengan Open Ended Problem untuk Meningkatkan Kemampuan Berpikir Kritis Mahasiswa Tadris Matematika IAIN Curup. Jurnal Pendidikan Matematika Raflesia, 4(1), 1-9. https://doi.org/10.33449/jpmr.v4i1.7523

Maria Inawati. (2011). Meningkatkan minat mengenal konsep bilangan melalui metode bermain alat manipulatif. Jurnal Pendidikan, 16(Tahun ke10), 1-10. http:/ / bpkpenabur.or.id/wp-content/uploads/2015/10/jurnal-No16-Thn10Juni2011.pdf\#page $=9$

Ministry of Education and Culture of Republic Indonesia. (2014). National Standard of Early Children Education. 1-15.

Muin, A. (2016). Penerapan Pendekatan Open Ended Problems Dalam Meningkatkan Hasil Belajar Matematika Siswa Kelas V Sd Negeri 206 Ujung Baru Kabupaten Soppeng. Publikasi Pendidikan, 6(3). https:// doi.org/10.26858/publikan.v6i3.2290

Munroe, L. (2015). The Open-Ended Approach Framework. European Journal of Educational 
Research, 4(3), 97-104. https:// doi.org/10.12973/eu-jer.4.3.97

Nasional, D. P. (2007). Pedoman Pembelajaran Bidang Pengembangan Kognitif di Taman Kanak-Kanak. In Departemen Pendidikan Nasional Direktorat Jenderal Manajemen Pendidikan Dasar dan Menengah Direktorat Pembinaan Taman Kanak-Kanak dan Sekolah Dasar.

National Council Of Teachers Of Mathematics. (2000). Principles and Standards for School Mathematics. School Science and Mathematics, 47(8), 868-279. www.nctm.org

Nining Sri Ningsih. (2009). Pembelajaran Matematika Terpadu untuk Anak Usia Dini. Pustaka Sebelas.

Nopayana, S., Rostika, D., \& Ismail, M. H. (2018). Upava Meningkatkan Pemahaman Konsep Bilangan Beserta Lambang Bilangan Pada Anak Melalui Media Papan Flanel Modifikasi. Cakrawala Dini: Jurnal Pendidikan Anak Usia Dini, 7(1). https:// doi.org/10.17509/cd.v7i1.10545

Novianty, M. (2018). Learning Trajectories Based Inquiry Untuk Membangun Mathematical Knowledge for Teaching Guru Anak Usia Dini. Prisma, 7(2), 123. https:// doi.org/10.35194/jp.v7i2.234

Novtiar, C., \& Aripin, U. (2017). Meningkatkan Kemampuan Berpikir Kritis Matematis Dan Kepercayaan Diri Siswa Smp Melalui Pendekatan Open Ended. Prisma, 6(2), 119-131. https:// doi.org/10.35194/jp.v6i2.122

Nurkamilah, M., Mirawati, M., \& Arumsari, C. (2018). Disposisi Matematis Anak Usia Dini (Studi Kasus di Kelompok A PAUD Permata Hati Aisyiyah Tasikmalaya). EARLY CHILDHOOD : JURNAL PENDIDIKAN, 2(2b), 19-29. https:// doi.org/10.35568/earlychildhood.v2i2b.282

Rahman, T., Sumardi, S., \& Fuadatun, F. (2017). Peningkatan Kemampuan Anak Usia Dini Mengenal Konsep Bilangan melalui Media Flashcard. JURNAL PAUD AGAPEDIA, 1(1), 118-128. https://doi.org/10.17509/jpa.v1i1.7167

Roliana, E. (2018). Urgensi Pengenalan Konsep Bilangan Pada Anak Usia Dini. Prosiding Seminar Dan Diskusi Nasional Pendidikan Dasar 2018 Tema: Menyonsong Transformasi Pendidikan Abad 21, 2015, 417-420. http://journal.unj.ac.id/unj/index.php/psdpd/article/view/10172/6597

Ruseffendi, H. E. T. (2010). Perkembangan Pendidikan Matematika. Universitas Terbuka.

Sugiyono. (2017). Statistika untuk Penelitian. Alfabeta.

Sumardi, S., Rahman, T., \& Gustini, I. S. (2017). Peningkatan Kemampuan Anak Usia Dini Mengenal Lambang Bilangan Melalui Media Playdough. Jurnal Paud Agapedia, 1(2), 190-202. https://doi.org/10.17509/jpa.v1i2.9359

Suwardi, S., Firmiana, M. E., \& Rohayati, R. (2016). Pengaruh Penggunaan Alat Peraga terhadap Hasil Pembelajaran Matematika pada Anak Usia Dini. JURNAL Al-AZHAR INDONESIA SERI HUMANIORA, 2(4), 297. https:/ / doi.org/10.36722/sh.v2i4.177

Wahyudin, U., \& Agustin, M. (2011). Penilaian perkembangan anak usia dini. Bandung: Refika Aditama.

Winitri, R., \& Nurani, Y. (2020). Perbedaan Hasil Belajar Matematika Anak Usia 6-7 Tahun ditinjau dari Pemahaman Guru Abstrak. Jurnal Obsesi : Jurnal Pendidikan Anak Usia Dini, 4(2), 491-501. https://doi.org/10.31004/obsesi.v4i1.402

Wulandari, N. P. R., Dantes, N., \& Antara, P. A. (2020). Pendekatan Pendidikan Matematika Realistik Berbasis Open Ended Terhadap Kemampuan Pemecahan Masalah

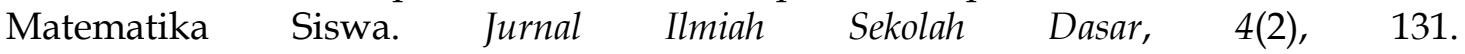
https:// doi.org/10.23887/jisd.v4i2.25103 